\title{
Tethered Spinal Cord Syndrome
}

National Cancer Institute

\section{Source}

National Cancer Institute. Tethered Spinal Cord Syndrome. NCI Thesaurus. Code C99080.

A progressive neurological disorder characterized by the limitation of movement of the spinal cord within the spine. It is caused by the presence of congenital or acquired tissue attachments in the spinal cord. Signs and symptoms include low back pain, scoliosis, weakness in the legs, and incontinence. 